\title{
Writing Across The Curriculum At The City University Of New York
}

Rosemary Iconis, (Email: ricon17@optonline.net), Queensborough Community College of the City University of New York

\begin{abstract}
The City University of New York appreciates that advanced writing ability is the distinguishing feature of an all-encompassing college education and that this ability can only be developed through extensive writing practice, fostered across an array of academic disciplines. In 1999 CUNY launched a major five year University initiative intended to both concentrate efforts and broaden the scope of the City University of New York's endeavor to teach writing in courses across the curriculum.
\end{abstract}

\section{PREFACE}

$\mathrm{n}$ the early 1970s nearly half of the entering freshmen at UC Berkeley, a university attracting some of the top graduates in the United States, were ending up in remedial writing classes. The situation was the rule rather than the exception at many of the nation's colleges and universities. In an effort to tackle the problem from the secondary school level, the National Writing Project was born. For the last twenty two years more than a million teachers have voluntarily participated in programs which endeavor to enhance writing instruction in the schools (Smith, 1996).

Unquestionably, skilled writing is a complex cognitive task. It must reflect the needs and sophistication of the audience. It is a process and product of critical thought which calls upon the skills of analysis, synthesis and evaluation. So, it cannot be completely unexpected that two decades later, the 1997 National Assessment of Educational Programs found that $60 \%$ of $12^{\text {th }}$ graders read at or below the "basic" level (Donahue, Voelkl, Campbell, \& Mazzeo, 1999). As reported in the literature (Henk, Marinak, Moore, Mallotte, 2003), these findings are corroborated by the annual "Reality Check" surveys conducted by Public Agenda in association with Education Week. When asked to rate recent high school graduates on their "ability to write clearly," $73 \%$ of employers and $75 \%$ of college professors described it as "fair" or "poor."

Fueled by the awareness that writing is a powerful tool both as a means of engaging students and developing their thinking and communication skills, the movement known as writing across the curriculum spread across the landscape of American higher education.

\section{INTRODUCTION}

A decade ago, those who study employment trends generally agreed that by today, many jobs would involve some degree of computer literacy which would mean much more than clerical or mechanical skills. The productive capacity of America will increasingly depend on the ability of an ever-growing portion of the work force to communicate in writing, both within and outside an organizational unit, from one person to another and one community to another (Russell, 1990).

The City University of New York appreciates that advanced writing ability is the distinguishing feature of an all-encompasing college education and that this ability can only be developed through extensive writing practice, fostered across an array of academic disciplines. In 1999 CUNY launched a major five year University initiative intended to both concentrate efforts and broaden the scope of the City University of New York's endeavor to teach writing in courses across the curriculum. The initiative was linked to a CUNY Writing Fellows Program which place 
specially trained CUNY doctoral students on undergraduate campuses to assist faculty members in support of intensive writing instruction.

A University-wide Task Force comprised of faculty experienced in writing development in higher education was convened. A description of existing or previous writing across the curriculum activities on his or her campus was submitted by a representative from each campus of City University. From the descriptions, a University-wide summary of WAC initiatives was developed. The summary described four aspects of a comprehensive WAC program: 1) the writing policy at each campus as reflected in required writing courses and writing in the disciplines; 2) WAC and WID initiative, evidenced by writing intensive courses and paired courses; 3) faculty development initiatives; and 4) evaluation efforts. Finally, three subcommittees were established to review the components of a comprehensive writing across the curriculum program and develop recommendations for University-wide guidelines for a writing across the curriculum model. Each subcommittee contributed a set of recommendations (Universitywide Guidelines for Writing Across the Curriculum, 1999).

\section{INCREASING THE VISIBILITY OF WRITING ON CAMPUS}

During the past two decades, the writing across the curriculum movement has had a significant impact on tens of thousands of students, faculty and administrators in colleges and universities throughout the United States. The WAC movement postulates that writing is a unique mode of learning in all disciplines and that it introduces students to the discourse communities of various disciplines. The development of a WAC program involves the creation of a writing environment throughout the campus. Barnett and Rosen (1999) describe the creation of a "writing environment" as campus-wide recognition that writing is central to students' intellectual development and to their success in the wider world. It also means that writing is visible, understood, and accepted as a pertinent goal for teaching and learning across the disciplines. A campus-wide environment implies ongoing dialogue about writing and its relationship to thinking and learning among faculty as well as students, plus opportunities for faculty to exchange ideas and discuss issues in writing pedagogy. Finally, a writing environment necessitates a visible writing support system available for both faculty and students.

WAC is a movement which attempts to reform pedagogy rather than curriculum. Writing is a process of doing critical thinking and communicating the results of the critical thinking (Bean pg 3). Thus, WAC is tied to thinking and learning and endeavors to transform teaching as well as student writing. Creating interdisciplinary settings that promote the development of critical thought through writing is integral to the WAC philosophy.

Also integral to the WAC philosophy is the belief that writing should be infused throughout the college curriculum, occurring in many courses in all disciplines. The value of introducing writing into various disciplines of study may be more apparent for some areas of study that others. For physical education faculty, for example, the call for expanded writing across the curriculum may not seem applicable. Because physical education focuses on skills related to physical activity, writing may not be considered germane. Yet, the multiple benefits of writing in a physical education class have been well documented in the literature (Behrman, 2004; Klein (1999, 2000), Mandigo \& Holt, 2000; Olafson, 2002; Silverman \& Subramaniam, 1999; Sulzby \& Barnhart, 1992; Vacca \& Linek, 1992). Those who support the WAC movement guard against the false notion that writing is unrelated to or detracts from any particular subject area.

\section{WAC AT CUNY}

The January 25, 1999 City University of New York Board of Trustees Resolution, The Enhancement of Student Writing Skills, confirmed CUNY's commitment to support students in the development of their writing abilities. The Board mandated effort, known as the University-wide Writing Across the Curriculum Initiative was conceived as a program in which a singular set of goals, agreed upon by a University-wide Task Force comprised of faculty representatives from the various campuses of the City University of New York versed in writing across the curriculum, would be implemented on each CUNY campus according to its own needs. 
Following an examination of the policies and practices of the WAC programs already in existence in colleges and universities throughout the country and within CUNY, the subcommittee on WID and WAC Programs and Practices formulated a list of characteristics of successful WAC programs.

- Successful WAC programs recognize that writing is an effective means of learning in all disciplines and at all levels;

- Writing intensive courses in the subject areas build upon the foundation of formal writing courses to explore the subject matter and discourse conventions of the disciplines;

- $\quad$ On-going faculty development is essential to support program development;

- Writing centers and tutorial services serve students in subject courses and beyond the introductory level; and

- Successful programs require administrative and financial support for faculty development, reduced class sizes, and student support services.

- Writing courses of various kinds need to be required at all levels within a college curriculum: foundation college level writing course(s) are prerequisites and/or corequisites for writing intensive courses in the disciplines.

The subcommittee formulated a set of recommendations for developing writing intensive courses based upon the characteristics of successful programs.

- Informal "writing to learn" activities should take place throughout the semester.

- Students in all WI courses should write a minimum of 10-12 pages of formal writing, which will incorporate opportunities for revision and which can be satisfied by a variety of writing assignments.

- Instructors should be encouraged to use a series of short assignments rather than one long one and integrate writing into the course throughout the semester.

- $\quad$ Research papers (if assigned) should be completed so that students profit from instructional mediation and feedback.

- $\quad$ Course grades in WI courses should be based in substantial part on assessment of students' written work. (Office of Academic Affairs, 1999).

Two of the most important features of successful experiences for WAC in the colleges are (1) well designed, supported, and sustained faculty development and its partner (2) a Writing Fellows Program. Tori Haring-Smith (1992) identified two principal aims of a writing fellows program. The first aim is that faculty should assume a shared responsibility for supporting the writing of their students. A three-way partnership occurs in which students are responsible for submitting thoughtful drafts, writing fellows are responsible for providing useful and diplomatic feedback, and faculty are responsible for designing quality assignments and overseeing them through completion. The second aim is to foster the association of writing with learning. Writing as a mode of learning requires copiousness. The assistance of writing fellows encourages the revision of students' work, one of the most important aspects of writing and learning (Leahy, 1999). The three distinguishing features of a writing fellows program are:

- $\quad$ The project takes place all over campus, rather than requiring students to go to the Writing Center.

- $\quad$ All students in a class are involved, strong writers as well as weak. Students do not have to self-identify as needing help with their writing.

- $\quad$ The project "assists individual faculty members with assignment design and models for them in a direct and immediate way, methods of responding to student writing"(Haring Smith, 1992).

In support of the Writing Fellows Program, the initial City University-wide faculty development activities included a two day Professional Development Seminar over the summer for the writing fellows assigned to each campus and the faculty members who would be working with the writing fellows and the WAC initiative. While the Summer Institute provided critical opportunities for establishing the groundwork for effective working relationships between faculty members and writing fellows and continuing university exchange, each college was to define for itself the best use of the writing fellows and how the WAC program would be implemented. 
The writing fellows selected and trained for the CUNY WAC Initiative are all CUNY advanced doctorallevel students. It is a collaborative CUNY effort in as much as the program broadens the professional training and experience of CUNY graduate students, who in turn, assist CUNY undergraduates in improving their writing skills.

Professional development workshops are provided for all faculty members who elect to join the WAC initiative. They have proven to be invaluable for attendees. They provide a forum for collaborative learning in which faculty members help each other. The workshops keep writing visible throughout the colleges and provide an opportunity for faculty to share insights with colleagues.

At Queensborough Community College of the City University of New York, two sets of workshops are offered. One set of workshops, offered about once a month, are conducted for the general faculty population who want to give writing a more prominent role in their classes. These workshops are intended to promote the writing environment on campus and to attract new faculty who might be interested in becoming a part of the WAC program. The second set of faculty development workshops are full day, intensive workshops for faculty preparing to introduce writing into their specific disciplines.

After completing two years of piloting the Queensborough Community College of the City University of New York Writing Across the Curriculum (WAC) Program, the project Directors evaluated the implementation of the program.

In order to gain an awareness of how the 'writing intensive' courses were being conducted, the Directors conducted interviews with the faculty and requested portfolios from all WI faculty. The portfolios were to be submitted to the WAC Directors and then to the WAC sub-committee of the Queensborough Community College Faculty Senate Curriculum Committee for consideration. The portfolio was to include: the course syllabus, all writing assignments, representative samples of student writing from each assignment (both early drafts and final drafts), and a cover letter that ruminates about the successes and failures of the course.

The Directors concluded that the interviews served as an important source of information about the program's implementation and, at the same time, served to support a sense of community among the faculty and between the faculty and the program directors. It was suggested, that in the future, each faculty member's portfolio should be accessible during the interview.

The WAC workshops were deemed useful to promote discussions about pedagogy, and specifically, writing on campus. Suggestions for the future include creating space in each department for writing fellows, working with veteran WI faculty within departments to present workshops and creating reading groups around WAC literature.

In 2004 a research project conducted under the auspices of the WID/WAC and Faculty Executive Committee Awards for Classroom Research looked at students' attitudes towards the 'writing intensive courses' at Queensborough Community College of CUNY. Most students concluded that, compared to a traditional lecture course, the 'writing intensive' course required more effort but enhanced their understanding of the course material and improved their writing skills (Bales, 2004).

\section{CONCLUSIONS}

College students consistently rate communication skills, namely speaking, reading and writing effectively, as essential to their future success in the workplace (Zekeri, 2004). Faculty members who participate in the Writing Across the Curriculum Initiative at the City University of New York have been called upon to use their skills as innovators in the classroom to recreate their courses so that our students may achieve their goals for the future. By emphasizing writing as a mode of learning, faculty invite students to be active participants in their learning. The WAC Initiative at CUNY, a collaborative effort of administrators, faculty, writing fellows and students is increasingly becoming part of the teaching and learning environment at our colleges. 


\section{REFERENCES}

1. Bales, P. (2004). Students' attitudes toward a writing intensive course. Social sciences/history at CETL conference on best practices and the scholarship of teaching.

2. Barnett, R. W. and Rosen, L. M. (1999). Writing centers and writing across the curriculum programs: Building interdisciplinary partnerships. Greenwood Press.

3. Bean, J. C. (1996). Engaging Ideas: The professor's guide to integrating writing, critical thinking, and active learning in the classroom. Jossey-Bass Inc.

4. Behrman, E. H. (2004). Writing in the physical education class: Writing assignments in physical education, in addition to enhancing general literacy, have content-specific values-such as reinforcing key concepts and they are easy to implement! Journal of Physical Education, Recreation, \& Dance, 75(8) 22-29.

5. CUNY Office of Academic Affairs. (1999). University-wide guidelines for writing across the curriculum. Unpublished manuscript.

6. Donahue, P. L., Voelkl, K. E., Campbell, J. R., and Mazzeo, J. (1999). The NAEP 1998 reading report card for the nation and the states. U.S. Department of Education, Office of Educational Research and Improvement.

7. Haring-Smith, T. Changing students attitudes: Writing fellows programs. In S.H. McLeod \& M. Soven (Eds.) Writing across the curriculum: A guide to developing programs. Sage, 175-187.

8. Henk, W. A., Marinak, B. A., Moore, J. C., and Mallette, M. H. (2003). The writing observation framework: A guide for refining and validating writing instruction. The Reading Teacher, 57(4), 322-335.

9. Klein, P. D. (1999). Reopening inquiry into cognitive processes in writing-to-learn. Educational Psychology Review, 11, 203-270.

10. Klein, P. D. (2000). Elementary students' strategies for writing-to-learn in science. Cognition \& Instruction, $18,317-348$.

11. Leahy, R. (1999). When a writing center undertakes a writing fellows program. In R. W. Barnett and J. S. Blumner (Eds.), Writing centers and writing across the curriculum programs: building interdisciplinary partnerships. Greenwood Press, 71-87.

12. Mandigo, J. L. and Holt, N. L. (2000). Putting theory into practice: How cognitive evaluation theory can help us motivate children in physical activity environments. Journal of Physical Education, Recreation, \& Dance, 71(1), 44-49.

13. Olafson, L. (2002). I hate phys ed. Adolescent girls talk about physical education. The Physical Educator, 59, 67-74.

14. Russell, D. R. (1990). Writing across the curriculum in historical perspective: Toward a social interpretation. College English, 52(1), 52-73.

15. Silverman, S. and Subramaniam, P. R. (1999). Student attitudes toward physical education and physical activity: A review of measurement issues and outcomes. Journal of Teaching in Physical Education, 18, $97-$ 125.

16. Smith, M. A. (1996). The national writing project after 22 years. Phi Delta Kappa, 77(10), 688-673.

17. Sulzby, E. and Barnhart, J. (1992). The development of academic competence: All our children emerge as writers and readers. International Reading Association.

18. Vacca, R. T. and Linek, W. M. (1992). Reading-writing connections: Learning from research. International Reading Association.

19. Zekeri, A. A. (2004). College curriculum competencies and skills former students found essential to their careers. College Student Journal, 29(1), 87-95. 


\section{NOTES}

